\title{
RHO Gene
}

National Cancer Institute

\section{Source}

National Cancer Institute. RHO Gene. NCI Thesaurus. Code C129078.

This gene plays a role in vision. 